\title{
How the Debt Crisis Exposes the Development of Solidarity in the Euro Area
}

\author{
Vestert Borger*
}

Concept of solidarity - Factual vs. normative solidarity - Development of solidarity in the euro area - Transition from negative to positive solidarity - Solidarity as a legal concept - European Stability Mechanism - European Financial Stabilisation Mechanism - European Financial Stability Facility - Pringle judgement of the Court of Justice of the European Union - ECB bond-buying programmes

\section{INTRODUCTION}

When the members of a group are not a perfect match, when being together requires an effort, then solidarity is key. The members of the euro area are not a perfect match. Before the introduction of the euro on 1 January 1999 it was questioned which of the member states would benefit from joining the euro area and which member states would be better off on their own. Economists would talk about this in terms of 'Optimum Currency Areas', a phrase used in economic theory to define the geographical area in which the conditions are most favourable for sharing a single currency. Given that a currency union is hardly ever optimum, they stressed the necessity of solidarity. To what extent are the members of the currency union willing to subordinate national interests for the sake of the common good in case of conflict? ${ }^{1}$ The debt crisis now puts solidarity in the euro area to the test. Financial rescue operations carried out during the last years are the most visible signs of this.

* PhD fellow at the Europa Institute of the University of Leiden. The euro crisis forms one of the focal points of the Institute's research. I am most grateful to Stefaan Van den Bogaert, Jorrit Rijpma, Alison McDonnell as well as the anonymous reviewers for their valuable comments on earlier versions of this paper. In addition, I would like to thank the participants of the Leiden Law Exchange (LLX) meeting on the Pringle ruling that took place on 8 Feb. 2013 in Leiden. This paper has benefited from the exchange of ideas that took place during that meeting. The usual disclaimer applies. E-mail: v.borger@law.leidenuniv.nl. This paper covers the developments in the crisis until 24 February 2013.

${ }^{1}$ See also B. Winkler, 'Towards a Strategic View on EMU: A Critical Survey', 16 Journal of Public Policy (1996) p. 1 at p. 14. 
As a result of these rescue operations, the issue of solidarity has come to occupy the minds of scholars of European law. This is not to say that solidarity was of no concern to them before. As a characterizing value of the Union, the notion of solidarity occupies an important place in the EU treaties. ${ }^{2}$ In addition, solidarity features in numerous other treaty provisions. Article 3(3) TEU, for example, tasks the Union with the promotion of intergenerational solidarity. The same provision also speaks about the promotion of solidarity among the member states and identifies it as an objective of the Union. Moreover, the Charter of Fundamental Rights has devoted a whole title to solidarity in the context of welfare related rights. ${ }^{3}$

But the actual importance of solidarity, notably between the member states, has undeniably shown up in the debt crisis. For proof, take the opinion of Advocate-General (AG) Kokott in Pringle. ${ }^{4}$ In this case the European Court of Justice was called to rule on the compatibility of the permanent rescue fund of euro area member states, the European Stability Mechanism (ESM), with Union law. According to AG Kokott, prohibiting member states from granting assistance to their European partners in a case of emergency would run counter to the basic fundamental principle of solidarity and, therefore, to the very purpose and objective of the Union. ${ }^{5}$

The present paper takes up the issue of solidarity between euro area member states and discusses its legal dimension in the light of the debt crisis. The above statement of AG Kokott may serve as a pointer. First of all, this paper is not concerned with the identification and delimitation of the principle of solidarity in Union law as such. ${ }^{6}$ It will not necessarily lead to an understanding of other kinds of solidarity with relevance for EU law, such as solidarity between member states and individuals in the context of free movement law or intergenerational solidarity. ${ }^{7}$ Secondly, the paper does not adopt a normative approach, arguing that more solidarity between member states is needed in order to overcome the crisis. Rather, in the realization that solidarity is more than a legal notion and has an

${ }^{2}$ Art. 2 TEU.

${ }^{3}$ Title IV of the Charter of Fundamental Rights of the European Union, OJ [2010] C 83/389.

${ }^{4}$ Case C-370/12, Thomas Pringle v. Government of Ireland, Ireland and the Attorney General [2012], n.y.p. (hereinafter 'Pringle').

${ }^{5}$ Opinion of AG Kokott in Case C-370/12, Pringle, paras. 142-144.

${ }^{6}$ See in this regard M. Ross, 'Solidarity: A New Constitutional Paradigm for the EU?', in M. Ross and Y. Borgmann-Prebil (eds.), Promoting Solidarity in the European Union (Oxford University Press 2010) p. 41-44.

${ }^{7}$ With regard to solidarity in the context of free movement law, see, e.g., F. de Witte, 'Transnational Solidarity and the Mediation of Conflicts of Justice in Europe', 18 European Law Journal (2012) p. 694-710. 
existence in full reality, the concept of solidarity is used descriptively and as an analytical tool to understand the legal developments arising from the debt crisis.

The paper starts from a conceptualization of solidarity and from an examination of the original treaty framework on EMU in the light of this conceptualization. By pointing to several rescue operations that have been carried out by the Union and the member states during the crisis it will subsequently argue that the solidarity between the members of the currency union has strengthened and even changed since the inception of EMU. The core of the paper will be about the legal dimension of this evolution. As a result of the strengthening of solidarity between euro area member states, Union law is put under strain. This forms the inevitable consequence of a treaty framework which is based on a notion of solidarity from the past. This paper argues that the current treaties can accommodate the changes in solidarity that have taken place until now. But further changes, whose signs are already visible, will make new amendments to the EU treaty eventually inevitable.

\section{SOlidARITY AND THE EURO}

\section{Conceptualizing solidarity between member states}

Solidarity is often associated, especially in social theory and related disciplines, with the relations between individuals making up a society, whether at the nationstate, regional or global level. ${ }^{8}$ The concept is also used, particularly in certain strands of international relations theory, to understand the cohesion between states. ${ }^{9}$ This paper draws inspiration from the ideas developed in these fields in order to conceptualize the bond between member states in the Union. In this regard, the following definition of solidarity may serve as a starting point: Solidarity is a mode of group cohesion, as a result of which individual members act in unison. ${ }^{10}$

As far as solidarity between member states is concerned, the Union can be regarded as the normative sphere in which they act in unison. Solidarity is what

\footnotetext{
${ }^{8}$ For a discussion of some of the uses of solidarity in classical sociology and modern social theory, see S. Stjernø, Solidarity in Europe. The History of an Idea (Cambridge University Press 2005) p. 25-39, 288-311.

${ }^{9}$ See M. Weber, 'The Concept of Solidarity in the Study of World Politics: towards a Critical Theoretic Understanding', 33 Review of International Studies (2007) p. 693-713; L. May, 'The International Community, Solidarity and the Duty to Aid', 38 Journal of Social Philosophy (2007) p. 185 at p. $191-195$.

${ }^{10}$ This definition is inspired by the much more elaborate definition used by W. Regh, 'Solidarity and the Common Good: An Analytical Framework', 38 Journal of Social Philosophy (2007) p. 7 at p. 8. In addition it is based on the theoretical discussion of social solidarity in G. Crow, Social Solidarities: Theories, Identities and Social Change (Open University Press 2002) p. 11.
} 
holds them together. For the purpose of this paper, therefore, solidarity is conceived of as a condition of unity, and hence, of order. ${ }^{11}$

Although the above definition of solidarity captures arguably the most basic feature of the notion, which is that behaviour is not determined solely by selfinterest but also out of a concern for the whole of which one forms part, it is too general to appreciate the dynamic and multifaceted nature of solidarity between member states. This exercise can be facilitated by examining the notion on the basis of two sets of polarities. The first relates to the motivation or the reason to adjust behaviour to the interest of the whole of which one forms part. The second has to do with the kind of behaviour being displayed.

As far as the motivation behind the behaviour is concerned, the polarities are, on the one hand, 'factual solidarity' and, on the other hand, 'normative solidarity.' Factual solidarity exists when the behaviour in the interest of the whole takes place on the basis of factual interdependence. Such solidarity is implicit; it underlies the interaction between member states. One may say that this kind of solidarity is at the basis of the cohesion between states in the Union. It can be traced back to Robert Schuman, one of Europe's founding fathers, who famously declared:

Europe will not be made all at once, or according to a single plan. It will be built through concrete achievements which first create a de facto solidarity. ${ }^{12}$ [L'Europe ne se fera pas d'un coup, ni dans une construction d'ensemble: elle se fera par des réalisations concrètes créant d'abord une solidarité de fait.]

This solidarity of fact relates to the ideas of Durkheim, one of the first thinkers about modern society, who distinguished between 'mechanical' solidarity, characteristic of traditional societies, and 'organic' solidarity, which exists in modern, heterogeneous societies. ${ }^{13}$ In such modern societies, it is factual interdependence that holds the members of a society together. ${ }^{14}$

Normative solidarity differs from factual solidarity as it does not merely exist by virtue of factual interdependence. It exceeds the level of implicitness that characterizes factual solidarity as it is understood and expressed as being a matter of the common good. On the basis of normative solidarity, therefore, behaviour occurs because it ought to take place in the interest of a common good. ${ }^{15}$ The central

\footnotetext{
${ }^{11}$ However, unlike some IR theories this paper does not adopt the normative view that nation state sovereignty is the fundamental precept of the possibility order. See also Weber, supra n. 9, p. $698,700-701$.

${ }^{12}$ Schuman Declaration, Paris, 9 May 1950.

${ }^{13}$ E. Durkheim, The Division of Labor in Society (The Free Press, Macmillan Publishing 1964) p. 129-138.

${ }^{14}$ See also WTE/DN, 'Rethinking Solidarity in the EU, From Fact to Social Contract', 7 European Constitutional Law Review (2011) p. 169 at p. 170.

${ }^{15}$ Regh, supra n. 10, p. 8.
} 
feature is that this solidarity is explicit and can be reasoned. Both factual and normative solidarity can exist at the same time and may influence each other.

With regard to the kind of behaviour that is being displayed a distinction can be made between 'negative' and 'positive' solidarity. ${ }^{16}$ In the case of negative solidarity, behaviour in the interest of the whole is essentially confined to the 'self'. The behaviour displayed by member states relates to themselves and is focused on their own condition, thereby simultaneously contributing to the interest of the whole. Positive solidarity, on the contrary, is behaviour that relates to the 'other'. Member states act in the interest of the whole by implementing behaviour that benefits other states. Again, both forms of solidarity, negative and positive, can be present at the same time.

Let us now see how the solidarity that originally existed between the member states in the EMU, and especially between those that make up the euro area, can be understood on the basis of this analytical scheme and how this may facilitate the understanding of the legal framework on EMU.

\section{Solidarity between the members of the currency union}

With the introduction of the euro on 1 January 1999, a factual solidarity between the members of the currency union was created, if only for the basic reason that they irrevocably fixed their exchange rates and abandoned their national currencies in favour of a European alternative. But there was a great normative dimension to their cohesion as well. The following sentence in a memorandum of 1995 from the hands of Theo Waigel, German finance minister in the Nineties, setting out the initial German proposal for a Stability Pact to stimulate budgetary discipline in EMU, is exemplary of this explicit, normative solidarity.

The monetary union must be committed to stability from the beginning. All participants in the final stage have the same interest in this. They form a community of solidarity in the sense that the stability of the common currency will be reliably and permanently secured through strict budgetary discipline in all the participating countries. ${ }^{17}$

\footnotetext{
${ }^{16}$ Although bearing resemblance, this distinction between 'negative' and 'positive' solidarity should not be fully equated with a similar distinction made by Durkheim, according to whom negative solidarity corresponds to a certain class of legal rules (i.e., real rights) as opposed to positive solidarity, which can be subdivided into mechanical and organic solidarity. See Durkheim, supra n. 13, p. 115-132. From a purely legal perspective, in relation to Art. 4(3) TEU, a distinction between negative and positive solidarity is also made by E.A. Marias, 'Solidarity as an Objective of the European Union and the European Community', 21 Legal Issues of European Integration (1994) p. 85 at p. 94 .

${ }^{17}$ T. Waigel, Proposal for a Stability Pact for Europe (November 1995), English translation available at <www.cvce.eu>. See also J-V. Louis, Managing Public Finances. Lessons and Perspectives for
} 
Waigel's statement is also instructive of the second set of polarities of solidarity, relating to the kind of behaviour being displayed. The solidarity between member states was predominantly negative in nature. Member state behaviour was mostly, yet not exclusively, focused on the self, based on the presumption that budgetary discipline would contribute to the achievement of price stability.

Before examining the original treaty provisions on the EMU in the light of this solidarity, it should be stated that there exists a complex relationship between the solidarity between member states and Union law. The law cannot simply be equated with solidarity. The former is, however, closely related to the latter. On the one hand, the law follows from and expresses the solidarity existing between member states. On the other hand, and because of the law's central role in constructing the Union as a normative sphere, it may also generate and strengthen solidarity between states. Needless to say, however, much of the law is not concerned with solidarity and that solidarity is not a merely legal phenomenon.

As to the factual/normative distinction, the treaty framework on EMU symbolizes and expresses both the factual and normative solidarity existing in the currency union. The most basic and visible form of factual solidarity, the interlocking of exchange rates, used to coincide with and was generated by the former Articles $4(2)$ and $123(4)$ of the EC Treaty on the transition to the third stage of EMU. ${ }^{18}$ Since the entry into force of the Lisbon Treaty, the fixing of exchange rates only features in Article 140(3) TFEU on member states that have not yet adopted the euro (i.e., 'member states with a derogation'). ${ }^{19}$ The normative dimension to the solidarity between the members of the currency union becomes clearly visible from several provisions referring to price stability, the Union's main monetary policy goal, ${ }^{20}$ as well as sound public finances. ${ }^{21}$

As to the negative/positive distinction, the negative solidarity underlying the euro finds clear recognition in four key prohibitions that are laid down in Articles 123-126 TFEU. The first three prohibitions aim to stimulate budgetary prudence on the side of member states by subjecting them to the discipline of the markets. ${ }^{22}$ Member states should, in principle, finance themselves on the markets just as

the EU and the Euro Area (Vortrag and der Humboldt-Universität zu Berlin, 15 Dec. 2010) p. 7-8 (referring to this phrase of the Waigel memorandum).

${ }^{18}$ See also Protocol No. 24 on the transition to the third stage of economic and monetary union, annexed to the TEC, OJ [2006] C $321 \mathrm{E} / 298$.

${ }^{19}$ The legal status of member states that have not (yet) adopted the single currency, which are called member states 'with a derogation', is regulated in Arts. 139-144 TFEU. Special regimes apply to the UK and Denmark. See Protocols No. 15 and 16 annexed to the TEU and TFEU.

${ }^{20}$ Art. 3(3) TEU; Arts. 119(2), 127(1) and 282(2) TFEU; Art. 2(2) of the Statute of the ESCB and ECB, laid down in Protocol No. 4 annexed to the TEU and TFEU (henceforth: Statute of the $\mathrm{ESCB}$ and $\mathrm{ECB})$.

${ }^{21}$ Art. 119(3) TFEU.

${ }^{22}$ R. Smits, The European Central Bank (Kluwer Law International 1997) p. 77-78. 
private entities have to do. When a member state's economic and budgetary policies are inadequate, this should lead the markets to charge higher risk premiums for buying up its bonds. In order to achieve this aim, Article 123(1) TFEU contains a prohibition on monetary financing, prohibiting both the ECB and national central banks (NCBs) from allocating credit to the Union or member state authorities, let alone directly purchasing government bonds from them. ${ }^{23}$ In addition, Article 124(1) TFEU forbids measures, not based on prudential considerations, establishing privileged access to financial institutions for Union or member state authorities. The latter two prohibitions are complemented by the ban on bailouts in Article 125(1) TFEU, according to which neither the Union nor the member states shall be liable for or assume the financial commitments of member state authorities. This prohibition aims to minimize the moral hazard problem that exists in any currency union by indicating that member states are on their own when, despite all the precautions incorporated in the Union legal framework, they let their budgets deteriorate, causing them difficulties to pay off their debt and refinance themselves at the markets. ${ }^{24}$

The fourth prohibition in Article 126(1) TFEU complements the rules on market discipline by prohibiting member states from having excessive government deficits and debts. What is to be understood as excessive follows from Article 1 of Protocol No. 12 on the excessive deficit procedure (EDP). A planned or actual government deficit in excess of $3 \%$ of GDP is considered to be excessive. Similarly, debts should not exceed $60 \%$ of GDP. ${ }^{25}$ Rather than expressing the negative solidarity between the members of the currency union, it may be argued that the prohibition on excessive deficits shows the lack of it. In support of this argument, one could refer to the fiasco that took place in 2003, when the Council proved unable to enforce the budgetary rules on France and Germany. ${ }^{26}$ However, one

${ }^{23}$ See also Art. 21(1) of the Statute of the ESCB and ECB.

${ }^{24}$ Smits, supra n. 22, p. 77-78; J-V. Louis, 'Guest Editorial: The No-Bailout Clause and Rescue Packages', 47 Common Market Law Review (CMLR) (2010) p. 971 at p. 978.

${ }^{25}$ In order to make sure member states indeed comply with these norms Art. 126 TFEU sets out the excessive deficit procedure (EDP) which is further worked out in the corrective part of the Stability and Growth Pact (SGP). Member states subject to an EDP may eventually face financial sanctions to be imposed by the Council. See Art. 126(11) TFEU; Regulation (EC) 1467/97 of 7 July 1997 on speeding up and clarifying the implementation of the excessive deficit procedure, OJ [1997] L 209/6, last amended by Regulation (EU) 1177/2011 of 8 Nov. 2011, OJ [2011] L 306/33.

${ }^{26}$ The institutional conflict that resulted from this failure to enforce the SGP between the Council and the Commission was eventually brought before the Court. See ECJ 13 July 2004, Case C-27/04, Commission of the European Communities v. Council of the European Union. For an analysis of the judgment, see D. Doukas, 'The Frailty of the Stability and Growth Pact and the European Court of Justice: Much Ado about Nothing?’, 32 Legal Issues of Economic Integration (2005) p. 293-312. 
should be careful about equating the lack of enforcement of the prohibition with a lack of negative solidarity itself. In fact, in 2007, just before the financial crisis set in on the European continent, most euro area member states reported deficits below the budgetary reference value of $3 \%$ of GDP. ${ }^{27}$

In line with the predominantly negative nature underlying the single currency, expressions of positive solidarity are much less represented in the legal framework on EMU. This form of solidarity becomes most visible in the assistance provisions of Article 122 TFEU, of which the first paragraph explicitly refers to solidarity, and Article 143(2) TFEU. Article 122(2) TFEU enables the Union to grant assistance when a Member state is in difficulties or is seriously threatened with severe difficulties as a result of natural disasters or exceptional occurrences beyond its control. Article 143(2) TFEU, which only applies to member states outside the euro area, allows the Council to decide on the granting of assistance in case such member states experience balance of payments problems.

It may be questioned why these assistance provisions relate to the solidarity between member states. After all, Article 122(2) TFEU specifically speaks of Union assistance. Moreover, the balance of payments assistance on the basis of Article 143(2) TFEU, although existing of credits of member states, is granted by the Council. However, both provisions can be perceived as expressions of the solidarity between member states. The following statement of the Court, rendered long before the introduction of the euro in 1969, about Article 108 EEC, the predecessor of the balance of payments assistance clause in Article 143 TFEU, is telling:

... The solidarity which is at the basis of these obligations as of the whole of the Community system in accordance with the undertaking provided for in Article 5 of the Treaty (now Art. 4(3) TEU), is continued for the benefit of the states in the procedure for mutual assistance provided for in Article 108 (now Art. 143 TFEU) where a Member State is seriously threatened with difficulties as regards its balance of payments. ${ }^{28}$

In other words, the assistance provisions can be seen as legal expressions of the solidarity that underlies the Union and holds member states together, ${ }^{29}$ and which finds specific recognition in Article 4(3) TEU. ${ }^{30}$

${ }^{27}$ Only Greece and Portugal reported deficits in excess of the 3\%. The statistics can be consulted in the database of Eurostat. See <epp.eurostat.ec.europa.eu/portal/page/portal/eurostat/home/>.

${ }^{28}$ ECJ 10 Dec. 1969, Case 11/69, Commission v. French Republic, para. 16.

${ }^{29}$ Marias, supra n. 16, p. 92-94.

${ }^{30} \mathrm{On}$ the issue of solidarity and the duty of loyal cooperation in Art. 4(3) TEU, see R. Bieber and F. Maiani, 'Sans solidarité point d'Union européenne - Regards croisés sur les crises de 1 'Union économique et monétaire et du Système européen commun d'asile', 48 RTD eur. (2012) p. 295 at p. 296; M. Ross, 'Promoting Solidarity: From Public Services to a European Model of Competition?', 44 CMLR (2007) p. 1057 at p. 1060-1063; R.St.J. MacDonald, 'Solidarity in the Practice 
The debt crisis teaches us that the solidarity between member states in the euro area has developed, and even strengthened, in comparison to the situation that existed at the time of the launch of EMU. It is this development of solidarity that can now be understood.

\section{THE DEVELOPMENT OF SOLIDARITY IN THE EURO AREA}

The assistance operations taking place in the euro area show that the solidarity between member states sharing the single currency has developed in several ways since the inception of EMU. First, the factual solidarity between these member states has increased as a result of the financial integration that has taken place over the past decade. This, in turn, has led to a change in normative solidarity as well. Additionally, a transition from negative to positive solidarity has taken place. Each of these developments will be considered below.

\section{The increase in factual solidarity}

Factual solidarity in the euro area has increased significantly after the launch of the euro. Interdependencies between member states intensified as a result of financial integration. But this increased interdependence, one of the most significant accomplishments of the single currency, carried with it a potential for destabilizing effects. $^{31}$

These effects materialized after the financial crisis flew over from the US and hit the European financial sector in the course of 2007. As a result of the turmoil in the financial sector, member states were forced to heavily support their troubled banks. Furthermore, in an effort to avert economies turning into recession, European governments implemented policies to support the real economy. ${ }^{32}$ No surprise these actions placed a great burden on member states' economies and budgets. This deterioration of member states' budgets created a lack of trust on the part of the financial markets that states which are currently experiencing severe financial problems will prove capable of restoring control over their budgets and improve their economies' competiveness. Doubts about the creditworthiness of member states, in turn, carry the potential of harming the European banking sector. Member states' government bonds are - to a great extent - still held by their domestic

and Discourse of Public International Law', 8 Pace International Law Review (1996) p. 259 at p. 295-301; Marias, supra n. 16, p. 94-97.

${ }^{31} \mathrm{~J}$. Pisany-Ferry, The Known Unknowns and Unknown Unknowns of the EMU (Brueghel Policy Contribution 2012/18), p. 4-5.

${ }^{32}$ For an overview of the policy responses of the Union and the member states in relation to the financial crisis, see L. Quaglia et al., 'European Perspectives on the Global Financial Crisis: Introduction', 47 Journal of Common Market Studies Supplement 1 (2009) p. 63-87. 
banks. Given that member states are responsible for rescuing banks in their jurisdictions, concerns about the solvency of a member state may also affect its banks, which in turn seriously destabilizes the European banking sector at large. ${ }^{33}$

The interdependence of euro area member states in combination with the vicious intertwining of sovereigns and banks forms one of the most important factors behind the assistance operations carried out during the debt crisis. ${ }^{34}$ The risk of contagion associated with either sovereign or banking defaults is simply too high. ${ }^{35}$ It is this solidarity of fact that to a great extent provides the rationale behind the assistance granted to Greece, Ireland, Portugal and Spain's ailing banking sector.

\section{The change in normative solidarity}

However, this strengthened solidarity of fact has triggered a change in normative solidarity between member states as well. Characteristic for this change is a departure from an economic policy that is predominantly focused on budgetary prudence and price stability to one that takes better into account financial stability as well. ${ }^{36}$ The first evidence of this change in normative, explicit solidarity can be found in a declaration that the Heads of State and Government of the Union issued on 11 February 2010 when it became clear that Greece would need assistance in order to avoid a disorderly default. In this declaration the change in normative solidarity is clearly visible: 'Euro area member states will take determined and coordinated action, if needed, to safeguard the financial stability in the euro area as a whole. ${ }^{37}$

In the run-up to the instalment of the first Greek assistance package similar statements were made on 25 March 2010 and 11 April 2010 by the heads of state or government and the member states of the euro area respectively. ${ }^{38}$ By now referrals to financial stability have become almost routine in statements relating to assistance operations and policy documents about the development of EMU.

${ }^{33}$ Pisany-Ferry, supra n. 31, p. 5.

${ }^{34}$ Although important, the sovereign-banking interdependence is not the only systemic weakness that has been revealed by the crisis. For an overview, see Z. Darvas, The Euro Crisis: Ten Roots, but Fewer Solutions (Bruegel Policy Contribution 2012/17).

${ }^{35}$ Ibid., p. 6.

${ }^{36}$ This is not to say that financial stability has not been a concern before at all, but the economic policy provisions in the treaties paid, besides Art. 127(5) TFEU, little attention to it. See also Pisany-Ferry, supra n. 31, p. 7.

${ }^{37}$ Statement by the Heads of State or Government of the European Union, Brussels, 11 Feb. 2010.

${ }^{38}$ Statement by the Heads of State or Government of the euro area, Brussels, 25 March 2010; Statement on the support to Greece by euro area Member States, Brussels, 11 April 2010. 


\section{The transition from negative to positive solidarity}

The strengthening of factual solidarity and the accompanying change in normative solidarity is accompanied by a transition from negative to positive solidarity. This transition seems to be the inevitable consequence of the strengthening of factual solidarity and the change in normative solidarity. Economic literature suggests that the crisis teaches that one cannot combine a system that is strongly focused on negative solidarity with an intertwining of sovereigns and banks. A strict ban on co-responsibility for member states' debts, a prohibition of monetary financing and an interdependence between sovereigns and banks cannot co-exist: at least one element of this 'impossible trinity' has to give. ${ }^{39}$ And this is indeed what seems to have happened during the crisis. In fact, two elements of this trinity have come under strain. Given that the interdependence between sovereigns and banks cannot be undone overnight, the assistance operations, motivated by the need to safeguard financial stability in the euro area, have put pressure on the no-bailout clause (Article $125 \mathrm{TFEU}$ ) and the prohibition on monetary financing (Article 123 TFEU). Five moments in time deserve specific attention in this regard.

Three out of these five moments relate to the establishment of emergency funds by the Union and the euro area member states and their relation to the prohibition on bail-out. The first moment was the decision of euro area member states, taken on 2 May 2010, to grant assistance worth EUR 80 billion to Greece. ${ }^{40}$ This assistance, accompanied by an additional EUR 30 billion from the IMF, was granted via the Greek Loan Facility (GLF), a set of pooled bilateral loans that were coordinated and administered by the Commission. ${ }^{41}$

The second event took place only a few days later when it became clear that the debt crisis would not stay confined to Greece but would affect other peripheral member states as well. After a crisis meeting of the Heads of State or Government of the euro area on 7 and 8 May 2010, ${ }^{42}$ the finance ministers of the euro area decided in the night of 9 to 10 May 2010 to establish a financial safety net for the euro area in the amount of EUR 500 billion, to be accompanied by an addi-

${ }^{39}$ See J. Pisany-Ferry, The Euro Crisis and the New Impossible Trinity (Brueghel Policy Contribution 2012/01).

${ }^{40}$ Statement by the Eurogroup, Brussels, 2 May 2010.

${ }^{41}$ The GLF is founded on two agreements that were concluded on 8 May 2010. The first concerns an intercreditor agreement among the euro area lender member states, containing the modalities of their involvement in the loan facility. The second forms a loan facility agreement which sets out the provisions governing the pooled bilateral loans. Both agreements be consulted on the website of the Greek ministry of finance. See <www.minfin.gr/content-api/f/binaryChannel/ minfin/datastore/30/2d/05/302d058d2ca156bc35b0e268f9446a71c92782b9/application/pdf/ sn_kyrwtikoimf_2010_06_04_A.pdf>.

42 'The day that tested limits of the Union', Financial Times, 11 May 2010. 
tional EUR 250 billion from the IMF. ${ }^{43}$ This safety net was made up of two separate rescue facilities: the European Financial Stabilisation Mechanism (EFSM) and the European Financial Stability Facility (EFSF). The EFSM is a Union law construct that is based on the assistance clause in Article 122(2) TFEU. ${ }^{44}$ It has a firepower of EUR 60 billion, which corresponds to the amount available to the Union's own resources ceiling for payment appropriations. ${ }^{45}$ The EFSF is a special purpose vehicle (SPV), comprising EUR 440 billion, that has its legal basis outside Union law. ${ }^{46}$ It constitutes a 'société anonyme' incorporated under Luxembourg law. Its legal basis proper therefore is its articles of incorporation. ${ }^{47}$ Further details concerning its functioning are laid down in a framework agreement concluded between the EFSF as a corporation and the euro area member states in their capacity as its shareholders. ${ }^{48}$

However, for the transition from negative to positive solidarity, the great moment was the European Council meeting of 28-29 October 2010. At this meeting the European Council decided to introduce a permanent stability mechanism which should replace the temporary facilities EFSM and EFSF. It invited its president Van Rompuy to undertake consultations with the member states 'on a limited treaty change required to that effect, not modifying Article 125 TFEU (no-bailout clause). ${ }^{39}$ At its subsequent meeting of 16-17 December 2010 it launched a simplified treaty revision procedure on the basis of Article 48(6) TEU to realize this aim. ${ }^{50} \mathrm{~A}$ third paragraph was to be added to Article $136 \mathrm{TFEU}$, a provision that specifically concerns euro area member states. This provision embodies both the change in normative solidarity and the transition from negative to positive solidarity:

${ }^{43}$ Council of the European Union (ECOFIN), Conclusions, Brussels, 10 May 2010, 9602/10.

${ }^{44}$ Council Regulation (EU) 407/2010 of 11 May 2010 establishing a European financial stabilization mechanism OJ [2010] L 118/1 (henceforth: Regulation 407/2010).

${ }^{45}$ Art. 2(2) Regulation 407/2010. The Commission is empowered on behalf of the EU to contract borrowings from the capital markets or from financial institutions. See Arts. 2(1) and 6(3) Regulation 407/2010.

${ }^{46}$ At its origin lies a decision of the representatives of the governments of the euro area member states 'taken within the Council.' See Council of the European Union, Decision of the representatives of the governments of the euro area Member States meeting within the Council of the European Union, Brussels, 10 May 2010, 9614/10. Such acts fall within the realm of international law. See K. Lenaerts and P. Van Nuffel, European Union Law (Thomson/Sweet \& Maxwell 2011) p. 929-931; H.G. Schermers, 'Besluiten van de vertegenwoordigers der Lid-staten; Gemeenschapsrecht?' [Decisions of the representatives of the Member States: Community law?], SEW (1966) p. 545 at p. 549-550.

${ }^{47}$ The articles of incorporation, as well as other important legal documents concerning the EFSF are available at <www.efsf.europa.eu>.

${ }^{48}$ EFSF Framework Agreement between the euro area Member States and the EFSF, available at <www.efsf.europa.eu> (henceforth: 'EFSF Framework Agreement').

${ }^{49}$ European Council, Conclusions, Brussels, 28-29 Oct. 2010, para. 1.

${ }^{50}$ European Council, Conclusions, Brussels, 16-17 Dec. 2010, paras. 1-2. 
The Member States whose currency is the euro may establish a stability mechanism to be activated if indispensable to safeguard the stability of the euro area as a whole. The granting of any required financial assistance under the mechanism will be made subject to strict conditionality. ${ }^{51}$

After the European Parliament, the European Commission and the European Central Bank had each submitted an opinion, ${ }^{52}$ the European Council adopted Decision 2011/199 on 25 March 2011 in order to add this paragraph to Article 136 TFEU. ${ }^{53}$

In parallel with this simplified treaty amendment procedure, euro area member states began working on the international Treaty governing the European Stability Mechanism (ESM), for which the amendment was thought to clear the way. The ESM Treaty, to which all euro area member states are party, was signed on 2 February $2011 .^{54}$ It entered into force on 27 September 2012 and was subsequently formally inaugurated on 8 October 2012 during the first meeting of the ESM's Board of Governors. ${ }^{55}$ The ESM forms an international institution governed by public international law and is located in Luxembourg. It has an authorized capital stock of EUR 700 billion. ${ }^{56}$ Of this amount EUR 80 billion consists of paid-in capital. The remaining amount consists of callable capital. ${ }^{57}$ This arrangement should ensure that the ESM has an effective lending capacity of EUR 500 billion. ${ }^{58}$ The emergency mechanism can provide financial assistance via several

${ }^{51}$ Ibid., Annex I.

${ }^{52}$ European Parliament Resolution of 23 March 2011 on the draft European Council Decision amending Art. 136 of the Treaty on the Functioning of the European Union with regard to a stability mechanism for Member States whose currency is the euro, OJ [2011] C 247 E/22 (henceforth: 'European Parliament Resolution on the draft European Council Decision amending Art. 136 TFEU'); Commission Opinion on the draft European Council Decision amending Art. 136 of the Treaty on the Functioning of the European Union with regard to a stability mechanism for member states whose currency is the euro, 15 Feb. 2011, COM(2011)70 final; Opinion of the European Central Bank of 17 March 2011 on a draft European Council decision amending Art. 136 of the Treaty on the Functioning of the European Union with regard to a stability mechanism for member states whose currency is the euro, 17 March 2011 (CON/2011/24), OJ [2011] C 140/8.

${ }^{53}$ European Council Decision (EU) 2011/199 of 25 March 2011 amending Art. 136 of the Treaty on the Functioning of the European Union with regard to a stability mechanism for member states whose currency is the euro, OJ [2011] L 1 91/1 (hereinafter: Decision 2011/199).

${ }^{54}$ Treaty establishing the European Stability Mechanism, Brussels, 2 Feb. 2012 (henceforth: ESM Treaty).

${ }^{55}$ Press release, 'European Stability Mechanism (ESM) is inaugurated', Luxembourg, 8 Oct. 2012, <www.esm.europa.eu/press/releases/20121008_esm-is-inaugurated.htm>. The Board of Governors is the ESM's highest decision making body. The governors are members of the governments of the ESM Members who have responsibility for finance. See Art. 5 ESM Treaty.

${ }^{56}$ Art. 8(1) ESM Treaty.

${ }^{57}$ Art. 8(2) ESM Treaty.

${ }^{58}$ Recital 6 ESM Treaty. It must be noted that it was initially foreseen that the EFSF would be able to provide new stability support until the ESM entered into force. Hereafter, the EFSF 
instruments, ranging from loans, bond purchases on the primary and secondary markets to the indirect recapitalization of banks. ${ }^{59}$ Any assistance granted is subject to strict conditionality. ${ }^{60}$

The other two magnum events are, in succession, the launching of two bond buying programmes by the ECB. It is important to recall that these programmes are inherently linked to the solidarity between euro area member states as they relate to the prohibition on monetary financing which symbolizes the normative solidarity focusing on price stability and the largely negative solidarity aimed at budgetary prudence. The first bond buying programme, called Securities Markets Programme (SMP), was announced by the Governing Council of the ECB right after euro area member states had decided to establish an extensive financial safety net, on 9 May $2010 .{ }^{61}$ On the basis of this programme, the ECB and euro area NCBs, which constitute the Eurosystem, ${ }^{62}$ conducted interventions in secondary markets for euro area government bonds (among other things). ${ }^{63}$ The formal aim was to address the malfunctioning of securities markets and to restore an appropriate monetary policy transmission mechanism. ${ }^{64}$ However, financial stability concerns most likely will also have influenced the decision of the Governing Council. ${ }^{65}$

would only stay involved in assistance programs in which it was already active. In accordance with recital 6 and Art. 39 ESM Treaty, until the complete run-down of the EFSF, the combined overall EFSF/ESM lending capacity would be set at EUR 500 billion. However, on 30 March 2012 the Eurogroup decided that, for a transitional period until mid-2013, the EFSF may engage in new assistance programs in order to ensure a full, fresh lending capacity of EUR 500 billion. The combined overall EFSF/ESM lending capacity was therefore set at EUR 700 billion. After mid-2013, the maximum ESM lending volume will be EUR 500 billion. According to Art. 11(2) of the EFSF Framework Agreement, the EFSF shall be liquidated at the earliest date after 30 June 2013 on which there is no financial assistance outstanding and funding instruments and any reimbursements due to member state guarantors have been repaid in full.

${ }^{59}$ For an overview of the assistance instruments, see Arts. 14-18 ESM Treaty. The list of financial assistance instruments may be reviewed and changed by the Board of Governors. See Art. 19 ESM Treaty.

${ }^{60}$ Arts. 3, 12(1) and 13(3) ESM Treaty.

61 'Europe Agrees Rescue Package', Financial Times (FT.Com), 9 May 2010; press release, 'ECB Decides on Measures to Address Severe Tensions in Financial Markets', Frankfurt am Main, 10 May 2010, available at <www.ecb.int/press/pr/date/2010/html/pr100510.en.html $>$. This decision was formally implemented by the Decision of the European Central Bank of 14 May 2010 establishing a securities markets programme (2010/281/EU), OJ [2010] L 124/8 (henceforth: Decision 2010/281/EU).

${ }^{62}$ The ECB and NCBs belonging to the Eurosystem conduct the monetary policy of the Union. See Art. 282(1) TFEU; Art. 1 of the Statute of the ESCB and ECB.

${ }^{63}$ In addition Eurosystem central banks could buy on the primary and secondary markets eligible marketable debt instruments issued by private entities incorporated in the euro area. See Art. 1 Decision 2010/281/EU.

${ }^{64}$ Recital 3 Decision 2010/281/EU.

${ }^{65}$ Pisany-Ferry, supra n. 39, p. 6. In Recital 2 of Decision 2010/281/EU the Governing Council of the ECB also refers to 'the exceptional financial market circumstances, characterized by severe 
The SMP was mainly used to buy bonds of peripheral euro area member states such as Greece, Portugal, Ireland and - especially since August 2011 when the crisis started to drive the interest rates of other member states upwards as well those of Spain and Italy. ${ }^{66}$ Yet, during the second half of 2011, and after the failure of the Italian prime minister Berlusconi to deliver on his implicit promise to implement economic reforms in return for the bond purchases, ${ }^{67}$ use of the SMP decreased.

But rising interest rates on peripheral euro area government securities forced the ECB to reconsider bond purchases in the summer of 2012. This became especially clear when ECB president Draghi declared on 26 July 2012 at a conference in London that the Bank would do 'whatever it takes' within its mandate to protect the single currency, and subsequently backed this up with the reassurance: 'Believe me, it will be enough. ${ }^{98}$ On 2 August 2012, the ECB announced that it stood ready to intervene again on sovereign bond markets. ${ }^{69}$ Subsequently, on 6 September 2012 the General Council of the ECB outlined the features of its new bond purchasing programme, the Outright Monetary Transactions Programme (OMT) ${ }^{70}$ Just like its predecessor, the SMP, ${ }^{71}$ this programme aims to safeguard an appropriate monetary policy transmission and the singleness of the monetary policy. However, the OMT differs from the SMP in several respects. First, under the OMT a member state's government bonds will only be bought once such a state has lodged an official request for stability support with the ESM. Second,

tensions in certain market segments that are hampering the monetary policy transmission mechanism' in order to motivate its decision to establish the SMP.

${ }^{66}$ 'ECB Buys up Italian and Spanish Debt', Financial Times (FT.Com), 7 Aug. 2011.

${ }^{67}$ Z. Darvas, 'The ECB's Magic Wand', 47 Intereconomics (2012) p. 266 at p. 266. See also the ECB press release that was published on 7 Aug. and is available at <www.ecb.europa.eu/press/pr/ date/2011/html/pr110807.en.html $>$. In this press release in the ECB inter alia 'welcomes' the announcements of the Spanish and Italian governments concerning new measures and reforms in the area of fiscal and structural policies and subsequently states that on the basis of 'these assessments' it will actively implement the SMP. Next to this general statement, on 5 Aug. 2011 then president of the ECB Jean-Claude Trichet and his successor Mario Draghi sent a letter to the Italian government, urging it to implement economic reforms. This letter was leaked to the Italian newspaper Corriera della Sera and was published on 29 Sept. 2011. An English version is available at <www.corriere.it/economia/11_settembre_29/trichet_draghi_inglese_304a5f1e-ea59-11e0-ae064da866778017.shtml>. See also R. Bieber, 'Observer, Policeman, Pilot? On Lacunae of Legitimacy and Contradictions of Financial Crisis Management in the European Union' (EUI Working Paper 2011/16), p. 1-2, 4-5.

${ }^{68}$ Verbatim - Speech by Mario Draghi, President of the European Central Bank, at the Global Investment Conference in London, 26 July 2012, <www.ecb.int/press/key/date/2012/html/ sp120726.en.html>.

${ }^{69}$ 'Draghi prepares for fresh bond buying', Financial Times (FT.Com), 2 Aug. 2012.

${ }^{70}$ ECB Press Release, 'Technical Features of Outright Monetary Transactions', Frankfurt, 6 Sept. 2012, <www.ecb.int/press/pr/date/2012/html/pr120906_1.en.html>.

${ }^{71}$ Following the Governing Council's decision to launch the OMT, the SMP was terminated. 
this time the ECB has made it explicitly clear that there are no ex ante quantitative limits on the amount of purchases. Third, the Eurosystem will receive the same treatment (i.e. pari passu) as other private or other creditors with respect to euro area government bonds purchased under the OMT. Although the OMT has not yet been made use of, its mere announcement has already had an effect: market conditions for Spanish and Italian bonds improved significantly during the following months. ${ }^{72}$

The fact that existing legal regulation is put under strain by the assistance operations is not very surprising. A crisis often comes with strain. The question here is to what extent the law can deal with this strain and accommodate the evolution of solidarity between member states.

\section{SOLIDARITY AND THE LAW}

When it comes to the ability of EMU law to accommodate the change in solidarity, three questions are particularly interesting. The first is whether the no-bailout clause in Article 125 TFEU can be reconciled with the granting of assistance by member states via a mechanism outside the Union treaties such as the ESM. The second question is whether and to what extent Article 122(2) TFEU can provide a legal basis, which it does in the case of the EFSM, for the granting of assistance to financially distressed member states. The third question has to do with the prohibition on monetary financing in Article 123 TFEU and its relationship with the bond buying programmes of the ECB.

In the Pringle case the European Court answered the first question. In addition, in its ruling it has touched upon the second question. The third question remains unanswered until this day, as the Court was not called upon to deal with it in the Pringle case. However, at the time of writing, cases against the OMT are pending before both the European Court as well as the Bundesverfassungsgericht (the German Constitutional Court, $B \operatorname{Verf} G) .{ }^{73}$ Each of the three questions will be considered in turn.

\footnotetext{
${ }^{72}$ Secondary market yields on Spanish government bonds with a remaining maturity of close to ten years have decreased from $6.58 \%$ to $5.34 \%$ between Aug. and Dec. 2012. Similarly, yields on Italian bonds have gone done from $6 \%$ to $4.54 \%$ in the same period. See also <www.ecb.int/stats/ money/long/html/index.en.html>.

${ }^{73}$ See Case T-492/12, Von Storch and others v. ECB, not yet decided. Furthermore, the BVerfG has signaled in its preliminary judgment concerning the ESM that it will pronounce itself on the compatibility of the bond buying programme with the German Constitution. See BVerfG, 2 BvR 1390/12, 12 Sept. 2012, para. 202. See also M. Wendel, 'Judicial Restraint and the Return to Openness: The Decision of the German Federal Constitutional Court on the ESM and the Fiscal Treaty of 12 Sept. 2012', 14 German Law Journal (GLJ) (2013) p. 21 at p. 49-51; K. Schneider,
} 


\section{The no-bailout clause and the ESM}

In the Pringle case the Court had to determine, among other things, whether the no-bailout clause can be reconciled with the change in solidarity between the euro area member states. In plain legal terms this means that it had to decide whether and if so to what extent the no-bailout clause in Article 125 TFEU allows the granting of assistance by the ESM in order to safeguard the financial stability in the euro area. ${ }^{74}$ But the Court found itself in a difficult situation in this regard. It could not simply state that Article 136(3) TFEU clears the way for assistance operations that would otherwise be prohibited by the no-bailout clause. Two facts in particular prevented it from taking this approach.

First, at its meeting on 28-29 October 2010 the European Council had called for an amendment 'not modifying the no-bailout clause. ${ }^{75}$ This statement seems to have been included in order to take away German concerns about the possible incompatibility of the ESM with the German Constitution. After all, the presence of the no-bailout clause in the Union treaties is one of the most important reasons why the $B \operatorname{Verf} G$ had concluded in its ruling on the Treaty of Maastricht that the currency union constitutes a Stabilitätsgemeinschaft (stability union). ${ }^{76}$ A departure from this concept might call into question Germany's participation in EMU. ${ }^{77}$

Secondly, and more importantly, when the Court had to render its ruling in the Pringle case the amendment of the TFEU had not yet entered into force. Given that the Czech Republic had not yet ratified Decision 2011/199 ${ }^{78}$ Article 136(3) was not incorporated into the TFEU at that time. ${ }^{79}$ But the ESM Treaty

'Yes But... One More Thing: Karlsruhe's Ruling on the European Stability Mechanism', 14 GLJ (2013) p. 53 at p. 57-58.

${ }^{74}$ Prior to the Court's judgment in the Pringle case a variety of interpretations of the no-bailout clause were suggested in academic literature, ranging from very strict to more permissive. For an overview of these interpretations, see V. Borger, 'The ESM and the European Court's Predicament in Pringle', 14 GLJ (2013) p. 129-131.

${ }^{75}$ European Council, Conclusions, Brussels, 28-29 Oct. 2010, para. 2.

${ }^{76}$ BVerfG, Cases 2 BvR 2134/92 \& 2159/92, 12 Oct. 1993, para. 90.

${ }^{77}$ See also Louis, supra n. 24, p. 977-978. Interestingly, in its preliminary judgment on the ESM the $B V$ erfG actually considered Art. 136(3) TFEU to provide an exception to Art. 125 TFEU that mitigates market discipline. See BVerfG, 2 BvR 1390/12, 12 Sept. 2012, paras. 232-233; Borger, supra n. 74, p. 137.

${ }^{78}$ At the time of writing this paper the Czech Republic still has not ratified Decision 2011/199.

${ }^{79}$ According to Art. 2 of Decision 2011/199 the initial plan was for the Decision to enter into force on 1 Jan. 2013. However, as the Czech Republic had at that time, as well as at the moment of writing this paper, not yet notified the Secretary-General of its approval, this deadline was not met. The Decision will now enter into force on the first day of the month following receipt by the Secretary General of the Council of all the notifications of approval by the member states in accordance with their respective constitutional requirements. For the current stage of the ratification procedure please consult the agreements database of the Council at <www.consilium.europa. eu/policies/agreements?lang=en>. 
was already operative. If the Court would rule that Article 136(3) TFEU clears the way for the ESM this would have as a consequence that the euro area member states would have contravened Article 125 TFEU by concluding and ratifying the ESM Treaty before the entry into force of Decision 2011/199. Indirectly, it would also have meant that euro area member states would have violated Article 125 TFEU by granting assistance via the temporary fund EFSF which, like the ESM, also does not have its legal basis in Union law.

In its judgment the Court managed to reconcile the ESM with the no-bailout clause. It started its analysis by stating that member states have the power to conclude between themselves an agreement for the establishment of a stability mechanism, provided that the commitments entered into in the context of such an agreement comply with Union law. ${ }^{80}$

It then adopted an interpretation of Article 125 TFEU consisting of three strands. First, what is clearly prohibited by the text of Article 125 TFEU is the granting of assistance that would result in the recipient member state being no longer responsible for its commitments to its creditors. ${ }^{81}$ Second, in line with the focus on budgetary discipline and price stability, any assistance granted may not have as a consequence that the incentive of the recipient member state to conduct a sound budgetary policy is diminished. ${ }^{82}$ Assistance must therefore be accompanied by strict conditionality. ${ }^{83}$ Third, budgetary prudence does not only constitute a goal in itself, but relates to the attainment of a higher objective, namely maintaining the financial stability of the currency union. ${ }^{84}$ According to the Court, the granting of assistance by a stability mechanism is therefore allowed, provided that: (1) the recipient member state stays responsible for its commitments to its creditors, (2) any assistance is granted subject to strict conditionality, and (3) this is indispensible to safeguard the financial stability of the euro area as a whole.

Given that the ESM Treaty complies with these conditions, the Court subsequently concluded that it does not violate the no-bailout clause. ${ }^{85}$ Moreover, as Article 136(3) TFEU merely confirms that member states have the power to grant assistance via a stability mechanism such as the ESM, the Court ruled that the conclusion and ratification of the ESM Treaty is not dependent on the entry into force of Decision 2011/199. ${ }^{86}$

${ }^{80}$ Case C-370/12, Pringle, paras. 68, 72, 109.

${ }^{81}$ Ibid., para. 136. See also S. Van den Bogaert and V. Borger, 'Rechterlijke interpretaties ESM op de pijnbank van de crisis' [Judicial Interpretations of the ESM on the Rack of the Crisis], Het Financieele Dagblad, 7 Dec. 2012 (raising the question of to what extent this requirement prohibits the Union and euro area member states from accepting a voluntary 'haircut' on Greek debt).

${ }^{82}$ Case C-370/12, Pringle, paras. 135-136.

${ }^{83}$ Ibid., para. 136.

${ }^{84}$ Ibid., para. 135

${ }^{85}$ Ibid., paras. 138, 142-143, 145-147.

${ }^{86} \mathrm{Ibid}$., paras. 184-185. 
Paradoxically, the Court has reconciled the change in solidarity with the nobailout clause by denying that this change has taken place. According to the Court, within the limits posed by Article 125 TFEU, member states have always had the possibility to grant assistance via a mechanism such as the ESM in order to safeguard financial stability in the euro area. Although one cannot lose sight of the difficult position of the Court in Pringle, this is a strained reasoning, especially in two respects.

First, it disregards the change in normative solidarity. Unlike the aims of sound public finances and, especially, price stability, ${ }^{87}$ the financial stability of the euro area has not received specific recognition as an objective of the no-bailout clause in the treaties. Although Article 127(5) TFEU refers to the ESCB's contributory role in relation to the stability of the financial system, ${ }^{88}$ it is hard to argue that this proves the safeguarding of the financial stability of the euro area to be an objective of the no-bailout clause. Rather, it seems that the drafters of the Treaty of Maastricht have underestimated the risk of sovereign debt problems for financial stability in a highly integrated currency union characterized by an interdependence between sovereigns and banks, and that we are only now experiencing the impossibility of applying the no-bailout clause with full rigour. ${ }^{89}$

Second, by reasoning that member states have always had the possibility to grant assistance in order to safeguard the financial stability of the euro area as a whole, the Court does not recognize the transition from negative to positive solidarity. The negative solidarity underpinning the no-bailout clause, relating to the 'self' and the budgetary discipline of each member state individually, ${ }^{90}$ has partly given way to positive solidarity, focusing on the 'other' and requiring the granting of assistance when this is necessary to safeguard the stability of the currency union. However, on a closer examination, this transition does shine through in the reasoning of the Court. By identifying financial stability as an objective of the no-

${ }^{87}$ See e.g., Art. 3(3) TEU (mentioning price stability as an objective of the Union) and Art. 119(3) TFEU (mentioning sound public finances and stable prices as guidelines for the economic policies of the Union and the member states).

${ }^{88}$ See also Arts. 3(3) and 25(1) of the Statute of the ESCB and ECB laid down in Protocol No. 4 annexed to the TEU and TFEU. The role of the ECB in relation to the safeguarding of financial stability has altered significantly after the introduction of the European Systemic Risk Board in the beginning of 2011. See Regulation (EU) 1092/2010 of 24 Nov. 2010 on European macro-prudential oversight of the financial system and establishing a European Systemic Risk Board, OJ [2010] L 331/1; Regulation (EU) 1096/2010 of 17 Nov. 2010 conferring specific tasks upon the European Central Bank concerning the functioning of the European Systemic Risk Board, OJ [2010] $\mathrm{L} 331 / 162$. On the role of the ECB in the area of prudential supervision before the entry into force of the ESRB see Smits, supra n. 22, p. 319-363.

${ }^{89}$ Pisany-Ferry, supra n. 31, p. 7. See also U. J. Schröder, 'Die Griechenlandhilfen im Falle ihrer Unionsrechtswidrigkeit', 64 DÖV (2011) p. 61 at p. 64 (dismissing the argument that Art. 125 TFEU could have been modified through practice so as to allow financial assistance to safeguard stability in the euro area as a whole).

${ }^{90}$ See also text to n. 22 supra. 
bailout clause, the Court has indirectly brought the provision into the sphere of positive solidarity. The identification of financial stability as an objective of the ban on bailouts makes it very difficult to define the scope of the prohibition, as a clear definition of financial stability is hard to give. ${ }^{11}$ Tommaso Padoa-Schioppa, former member of the ECB's Executive Board, explains it very clearly:

While monetary stability simply means price stability, no such straightforward definition exists for financial stability. Defining financial stability is notoriously difficult, and that is why people find it more convenient to define financial instability. ${ }^{92}$

Both the question of what financial stability is exactly, as well as the question of at what point that stability is at such risk that the granting of assistance is needed, can only be answered by determining just when positive solidarity - the granting of assistance - is called for.

\section{Article 122(2) TFEU and the EFSM}

In its judgment in Pringle, the Court finds that the assistance clause in Article 122(2) TFEU cannot provide a legal basis for a permanent stability mechanism focusing on the stability of the euro area as a whole. According to the Court, it only provides a legal basis for ad hoc financial assistance. ${ }^{93}$ This reasoning is in line with that of the European Council, which had concluded at its meeting of 16-17 December 2010, as well as in the actual decision amending the TFEU, that this provision 'will no longer be needed for such purposes. ${ }^{94}$ The Court's ruling and the European Council's statement both cast doubt on the legality of the EFSM which, together with the EFSF, formed the first action taken upon the change in normative solidarity. However, it does seem possible, be it with some stretching again, to read into Article 122(2) TFEU a legal basis for the EFSM.

In applying Article 122(2) TFEU, due regard must be had to the no-bailout clause in Article 125(1) TFEU and the prohibition on excessive deficits in Article

${ }^{91}$ There is no universally accepted definition of financial stability. See also G.J. Schinasi, 'Defining Financial Stability', IMF Working Paper 2004. The ECB defines financial stability as 'a condition in which the financial system - comprising of financial intermediaries, markets and market infrastructures - is capable of withstanding shocks, thereby reducing the likelihood of disruptions in the financial intermediation process which are severe enough to significantly impair the allocation of savings to profitable investment opportunities.' See also <www.ecb.europa.eu/pub/fsr/html/ index.en.html >.

${ }^{92}$ Speach of T. Padoa Schioppa, 'Central Banks and Financial Stability', Jakarta, 7 July 2003, $<$ www.ecb.int/press/key/date/2003/html/sp030707.en.html>.

${ }^{93}$ Case C-370/12, Pringle, para. 65. For an analysis of the importance of this statement for the outcome in the Pringle case, see Borger, supra n. 74, p. 128-129.

${ }^{94}$ European Council, Conclusions, Brussels, 16-17 Dec. 2010, para. 1; Recital 4 Decision 2011/199. 
126(1) TFEU, both expressions of negative solidarity. First, given that both Article 122(2) TFEU and Article 125 TFEU are treaty provisions, neither of them can take precedence over the other. ${ }^{95}$ The scope of the assistance clause can therefore only be defined by balancing it against the no-bailout clause. Now, from the legislative history relating to the Treaty of Maastricht it appears clearly that Article 122(2) TFEU is intended as a counterweight or an exception to Article 125(1) TFEU, ${ }^{96}$ even though it is not literally formulated as such. ${ }^{97}$ When carrying out this balancing exercise, the starting point should therefore be that Article 125 TFEU forms the basic assumption and Article 122(2) TFEU its exception. The application of this exception is in turn dependent on the fulfilment of several conditions that are laid down in the provision.

When applying these conditions, Article 126(1) TFEU comes into play. This is especially true for the first condition, according to which the recipient member state must be in difficulties or threatened with severe difficulties caused by an 'exceptional occurrence.' A member state's poor budgetary condition as such will not form an exceptional occurrence. If it were to do so, Article 126 TFEU and the Stability and Growth Pact (SGP) would be deprived of most of their meaning. ${ }^{98}$ Nevertheless, the case may be different when high deficits and debts are the consequence of a financial crisis of extreme proportions such as the one of 2008. Opinions differ on the question to what extent the exceptional occurrence has to constitute the main cause for a member state's threatening insolvency. ${ }^{99}$ At least

${ }^{95}$ L. Knopp, 'Griechenland-Nothilfe auf dem verfassungsrechtlichen Prüfstand', Neue Juristische Wochenschrift (2010) p. 1777 at p. 1779.

${ }^{96} \mathrm{~J}$. Pipkorn, 'Legal Arrangements in the Treaty of Maastricht for the Effectiveness of the Economic and Monetary Union, 31 CMLR (1994) p. 263 at p. 273-274; E. Gnan, 'Artikel 104b', in H. von der Groeben et al. (eds.), Kommentar zum EU-/EG-Vertrag, Artikel 102a-136a EGV (Nomos 1999) p. 90 at p. 96-98; U. Häde, 'Haushaltdiziplin und Solidarität im Zeichen der Finanzkrise', Europäische Zeitschrift für Wirtschaftsrecht (EuZW) (2009) p. 399 at p. 402-403; Louis, supra n. 24, p. 982-983; A. de Gregorio Merino, 'Legal Developments in the Economic and Monetary Union During the Debt Crisis: The Mechanisms of Financial Assistance', 49 CMLR (2012) 1613 at p. 1633.

${ }^{97}$ Art. 122(2) TFEU is not formulated as an exception similar to those relating to the free movement provisions (Arts. 45(3), 52 and 65 TFEU) or internal or external security (Arts. 346 and 347 TFEU).

${ }^{98}$ Häde, supra n. 96, p. 401; Louis, supra n. 24, p. 984-985.

${ }^{99}$ K. Hentschelmann, 'Finanzhilfen im Lichte der No Bailout-Klausel - Eigenverantwortung und Solidarität in der Währungsunion', EuR 2 (2011) p. 282 at 300. To the contrary, see Häde, supra n. 96, p. 403 (focusing on the economic and the financial crisis as the triggering factor for the difficulties experienced by a member state, regardless of the fact whether prior imprudent budgetary policies have contributed to the situation) Note however that in a later contribution he seems to have slightly modified his view, stating that the loss of control experienced by the member state in question should not in essence be the consequence of unsolid budgetary policies. See U. Häde, Die europäische Währungsunion in der internationalen Finanzkrise - An den Grenzen europäischer Solidarität?', EuR (2010) p. 854 at p. 859. 
as regards Greece, this does not seem to be the case, as the country was already coping with worrying debts and deficits before the start of the crisis. ${ }^{100}$ However, this country has never received assistance from the EFSM. ${ }^{101}$ The situation may be different for countries such as Ireland and Portugal, both of which have called upon the EFSM, where the crisis has had a greater part in causing the economic problems. ${ }^{102}$

The second requirement to be met is that the exceptional occurrence must be 'beyond the control' of the member state concerned. From this it follows that assistance can only be granted as a measure of last resort when the member state concerned cannot help itself in any other way. ${ }^{103}$ In the case of a member state threatened with a sovereign default, characterized by the inability to refinance debt in the wake of rising interest rates, the situation can be characterized as beyond its control. Similarly, in such a situation of severe difficulties (or at least the threat thereof), a further condition of Article 122(2) TFEU, seem to be present. ${ }^{104}$

Third, and in conformity with the view that it constitutes a carefully defined exception to the no-bailout clause, assistance can only take place under 'certain conditions.' Especially when it is given in order to help member states with ailing economies, as in the debt crisis, conditions relating to reform measures should be attached. ${ }^{105}$ The EFSM satisfies this condition, as any assistance granted by it goes accompanied with strict conditions. ${ }^{106}$

Lastly, given that the assistance is related to an 'exceptional' occurrence, it can only be provided on a temporary basis and must be stopped as soon as the events justifying it have come to an end. ${ }^{107}$ The EFSM complies with this last requirement, as it is certainly not intended to set up permanent capital flows to certain

${ }^{100}$ Knopp, supra n. 95, p. 1780; B. Marzinotto et al., 'Two Crises, Two Responses', Brueghel Policy Brief 1 (Brueghel 2010) p. 2. See, however, also Louis 2010, supra n. 24, p. 984-985 (seemingly not applying the reasoning that the financial crisis must constitute the main cause of budgetary problems and subsequently coming to the conclusion that also Greece should be able to benefit from support under Art. 122(2) TFEU).

${ }^{101}$ During the last years Greece has only received assistance via the GLF and, thereafter, the EFSF. The ongoing lending programme for Greece will in principle stay with the EFSF and will not be transferred to the ESM.

${ }^{102}$ Häde 2010, supra n. 99, p. 858; More critical comments on the use of Art. 122(2) in the case of Ireland and Portugal can be found in M. Rüffert, 'The European Debt Crisis and European Union Law', 48 CMLR (2011) p. 1777 at p. 1787.

${ }^{103}$ H. Rathke, 'Von der Stabilitäts- zur Stabilisieringsunion: Der neue Art. 136 Abs. 3 AEUV', DÖV (2011) p. 753 at p. 754; Häde 2010, supra n. 99, p. 858.

${ }^{104}$ Häde, supra n. 96, p. 403.

${ }^{105}$ Gnan, supra n. 96, p. 100; Louis, supra n. 24, p. 985; U. Häde, 'Artikel 100 EG-Vertrag', in Caliess et al. (eds.), Kommentar des Vertrages über die Europäische Union und des Vertrages zur Gründung der Europäischen Gemeinschaft-EUVIEGV (Luchterhand 2002) p. 1304 at p. 1306.

${ }^{106}$ Recital 7, Arts. 3(3)(b), 3(4)(b), 3(5), 4(2) and 5(2) of Regulation 407/2010.

${ }^{107}$ Louis, supra n. 24, p. 985. 
member states. ${ }^{108}$ However, it can be argued that the condition of 'exceptionality' not only relates to the temporary nature of the assistance, but also, and in line with the Court's statement that Article 122(2) TFEU does not provide a legal basis for a permanent stability mechanism, ${ }^{109}$ to that of the assistance instrument itself. But this requirement is also taken care due to the fact that the Commission is under an obligation to verify every six months whether the exceptional occurrences that led to the adoption of the EFSM are still present. ${ }^{110}$ Moreover, this issue is no longer of practical importance, as the ESM has taken over the tasks that were hitherto fulfilled by the EFSM and EFSF. ${ }^{111}$ The EFSM will not engage in any new lending programmes and will only stay active in existing programmes, namely those concerning Ireland and Portugal.

Despite the fulfilment of these conditions by the EFSM, one may still argue that it should not have been based on Article 122(2) TFEU, as this provision focuses on assistance to individual countries dealing with an exceptional occurrences beyond their control, whereas the overarching aim of the EFSM is to safeguard the financial stability of the Union. ${ }^{12}$ This may be seen to conflict with the Court's conclusion that Article 122(2) TFEU does not provide a legal basis for an assistance mechanism that has as its objective the safeguarding of the stability of the euro area as a whole. Nevertheless, and this is where most of the strain comes in, the fact that the preservation of financial stability, not only in the euro area but in the Union as a whole, forms the Leitmotiv of the EFSM does not mean that the mechanism is improperly based on Article 122(2) TFEU. Regulation 407/2010 creates the EFSM but not specific financial assistance operations. The latter still require a formal Council decision. ${ }^{113}$ The Council therefore has to assess whether a member state is coping with an exceptional occurrence beyond its control each time it considers to grant financial assistance. ${ }^{114}$

${ }^{108}$ See also Arts. 3(3)(a) and 3(4)(a) of Regulation 407/2010 which state that the Council decision to grant a loan or credit line must specify the availability period of the assistance.

${ }^{109}$ See however, Borger, supra n. 74, p. 128 (arguing that it is not so much the permanent nature of the mechanism itself, but the temporality of the assistance that matters).

${ }^{110}$ Art. 9(1) Regulation 407/2010.

${ }^{111}$ See Point 1 of the Preamble to the ESM Treaty. Note, however, that for a transitional period until mid-2013 the EFSF and the ESM run in parallel. See also n. 58 supra.

${ }^{112}$ The focus on the financial stability of the Union becomes apparent from several provisions in Regulation 407/2010, especially Recitals 4-5, 8 and Art. 1.

${ }^{113}$ Art. 3(2) Regulation 407/2010.

${ }^{114}$ Arts. 4(2) and 5(2) Regulation 407/2010; Rüffert, supra n. 102, p. 1787; Hentschelmann, supra n. 99, p. 303-304. 


\section{Article 123 TFEU and the bond buying programmes of the ECB}

Perhaps the most effective instruments in combating the crisis, which are not yet the subject of a ruling by the Court, ${ }^{115}$ are the bond buying programmes of the ECB, especially the second one, the OMT. Article 123(1) TFEU prohibits both overdraft facilities or any other type of credit facility with the ECB or NCBs in favour of both the Union and the member states as well as the purchase by the $\mathrm{ECB}$ or NCBs directly of debt instruments (i.e., 'primary market intervention'). Article 125(2) TFEU provides a legal basis for the adoption of specific definitions for the application of the prohibition. ${ }^{116}$ The Council has used this opportunity to adopt Regulation 3603/93/EC, which specifies several notions featuring in the provision. ${ }^{117}$

What is crucial in the current situation is that Article 123 TFEU only prohibits the purchase of bonds directly from member states and does not rule out the possibility that the ECB or NCBs intervene on the secondary markets to buy government bonds. ${ }^{118}$ The latter form of market intervention has been specifically left out as large and liquid bond markets are necessary to carry out open market operations, ${ }^{119}$ an important monetary policy instrument whereby securities are sold or bought to influence money market liquidity. ${ }^{120}$ Furthermore, such open market operations do not establish a direct financing relationship between the ECB or NCBs and member states. ${ }^{121}$ According to Article 18(1) of the statute of the ESCB and $\mathrm{ECB}$, the ECB and NCBs may intervene on the financial markets by buying and selling outright marketable debt instruments in order to achieve the objectives of the ESCB. ${ }^{122}$ However, improper use of the power to intervene

${ }^{115} \mathrm{~A}$ case against the OMT is pending before the Court. See text to n. 73 supra.

${ }^{116}$ Art. 125(2) TFEU also enables the adoption of definitions concerning Arts. 124 and 125 TFEU.

${ }^{117}$ Regulation (EC) 3603/93 of 13 Dec. 1993 specifying definitions for the application of the prohibitions referred to in Arts. 104 and 104b(1) of the Treaty, OJ [1993] L 332/1 (henceforth: Regulation 3603/93). As becomes apparent from the title of the Regulation, this instrument also contains definitions concerning Art. 125 TFEU.

${ }^{118}$ Art. 2(2) of Regulation 3603/93 provides for an exception to the prohibition on direct purchases in relation to the management of foreign exchange reserves. The ECB and the NCBs belonging to the Eurosystem are still allowed to purchase directly government debt instruments of a member state outside the euro area if this happens for the sole purpose of managing foreign exchange reserves. Similarly, the NCBs of member states outside the euro area can still conduct direct purchases of government securities of another member state. See also Smits, supra n. 22, p. 293-295.

${ }^{119}$ E. Gnan, 'Artikel 104', in H. von der Groeben et al. (eds.), Kommentar zum EU-/EGVertrag, Artikel 102a-136a EGV (Nomos 1999) p. 62 at p. 76.

${ }^{120}$ P. De Grauwe, Economics of Monetary Union (Oxford University Press 2009) p. 215.

${ }^{121}$ Gnan, supra n. 119, p. 76; D. Hattenberger, 'Artikel 101', in Schwarze et al. (eds.), EUKommentar (Nomos 1999), p. 1187 at p. 1189.

${ }^{122}$ Art. 18 of the Statute of the ESCB and ECB does not apply to NCBs of member states with a derogation. See Arts. 42(1) and 42(2) of the Statute of the ESCB and ECB. 
on secondary markets may serve as a tool to financially support member states. For that reason, the preamble of Regulation 3603/93 bans purchases on the secondary market to circumvent the objective of Article 123 TFEU. ${ }^{123}$

Some hold that the buying programmes violate Article 123 TFEU. They argue that the secondary market interventions are not focused on supporting the Eurosystem's monetary policy focused on price stability, but would in essence be aimed at lowering the interest rates for bonds of financially distressed member states. These interventions would therefore run counter to the objective of Article 123 TFEU. ${ }^{124}$ In addition, they point to the fact that Article 18(1) of the Statute of the ESCB and ECB only allows the purchase of marketable debt instruments. Since markets for several peripheral bonds, especially Greek ones, had nearly dried up when the first programme, the SMP, was launched in May 2010 these interventions would not have concerned marketable instruments. ${ }^{125}$

However, also in the case of Article $123 \mathrm{TFEU}$ it seems possible to reconcile the law with practice. To begin with, the interventions do not seem to run counter to the objective of Article $123 \mathrm{TFEU}$. One might say that this provision pursues a three-fold objective. ${ }^{126}$ First, it intends to enhance budgetary discipline by ruling out the possibility that member states can obtain credit on beneficiary terms by resorting to central bank credit. In principle, member states have to borrow in the markets on the same terms and conditions as private entities. Second, by enhancing budgetary discipline the prohibition aims to contribute to the achievement of price stability. Third, the prohibition tries to strengthen central bank independence by ruling out the possibility that monetary financing obstructs the ESCB's efforts to achieve price stability. ${ }^{127}$

The SMP and especially its successor, the OMT, comply with these objectives. Concerning price stability the OMT aims, just like the SMP did, ${ }^{128}$ to safeguard

${ }^{123}$ Recital 7 Regulation 3603/93.

${ }^{124}$ M.C. Kerber and S. Städter, 'Die EZB in der Krise: Unabhängigkeit und Rechtsbindung als Spannungsverhältnis - Ein Beitrag zum Individualrechtsschutz gegen Rechtsverstösse der EZB', 22 $E u Z W(2011)$ p. 536 at p. 537; A. Belke, 'Driven by the Markets? ECB Sovereign Bond Purchases and the Securities Markets Programme’, 45 Intereconomics (2010) p. 357 at p. 357; D. Meyer, 'Stabilitätsgefähren für die EWU', 90 Wirtschaftsdienst (2010) p. 805 at p. 808-809; Rüffert, supra n. 102 , p. $1787-1788$.

${ }^{125}$ M. Seidel, 'Der Ankauf nicht markt- und börsenängiger Staatsanleihen, namentlich Griechenlands, durch die Europäische Zentralbank und durch nationale Zentralbanken - rechtlig nur fragwürdig oder Rechtsverstoss?', 21 EuZW (2010) p. 521 at p. 521; Rüffert, supra n. 102, p. 1788.

${ }^{126}$ P. Athanassiou, 'Of Past Measures and Future Plans for Europe's Exit from the Sovereign Debt Crisis: What Is Legally Possible (and What Is Not)', 36 European Law Review (2011) p. 558 at p. 567.

${ }^{127}$ See also Gnan, supra n. 119, p. 62 at p. 66-67; Hattenberger, supra n. 121, p. 1188.

${ }^{128}$ Recital 3 Decision 2010/281/EU. 
an appropriate monetary policy transmission mechanism - i.e. the process through which the ECB's monetary policy decisions influence the real economy ${ }^{129}$ - and thereby the effective conduct of monetary policy oriented towards price stability in the medium term. ${ }^{130}$ Moreover, and similar to the SMP, ${ }^{131}$ in order to ensure that purchases of the ECB do not result in an increase of the money supply, under the OMT the impact of the operations will be 'sterilized' by re-absorbing any injected liquidity. ${ }^{132}$ With regard to budgetary discipline, it should first of all be stated that, in conformity with Article 123(1) TFEU, no primary market sovereign bond purchases take place. Disregarding any aid received from emergency funds, euro area member states are therefore still subject to the market mechanism when it comes to refinancing their debts. ${ }^{133}$ Moreover, if there were problems to guarantee budgetary discipline under the SMP, as exemplified by the situation of Italy in the summer of 2011, these have been addressed by the OMT. Under the new programme, interventions will only take place once a particular member state has lodged a request for stability support with the ESM and has committed itself to an adjustment programme. ${ }^{134}$ This link with the ESM may also safeguard central bank independence, as it prevents the ECB from getting too closely involved with the politics associated with adjustment programmes and economic reforms. The Governing Council of the ECB has announced it will stop its interventions in case a member state does not comply with a programme. ${ }^{135}$

Moreover, with regard to the issue of the 'marketability' of debt instruments, it is argued that instead of looking whether markets for sovereign bonds are, in reality, sufficiently liquid, instruments can be regarded as marketable when they

${ }^{129}$ For a detailed chart containing a schematic illustration of the various transmission channels of the ECB's monetary policy decisions, see <www.ecb.europa.eu/mopo/intro/transmission/html/ index.en.html>.

${ }^{130}$ See European Central Bank, Montly Bulletin October (ECB 2012), p. 8-9.

${ }^{131}$ See ECB Press Release, 'ECB decides on measures to address severe tensions in financial markets', Frankfurt, 10 May 2010, <www.ecb.europa.eu/press/pr/date/2010/html/pr100510. en.html>.

${ }^{132}$ See ECB Press Release, 'Technical Features of Outright Monetary Transactions', Frankfurt, 6 Sept. 2012; C. Herrmann, 'Die Bewältigung der Euro-Staatsschulden-Krise an den Grenzen des deutschen und europäischen Währungsverfassungsrechts', 23 EuZW (2012) p. 805 at p. 811. See, however, Belke, supra n. 124, p. 360-361 (expressing doubts about the technique used for and the effectiveness of the ECB's sterilization measures under the SMP).

${ }^{133}$ See Herrmann, supra n. 132, p. 811. See also Darvas, supra n. 67, p. 267 who states: 'The ECB would purchase bonds only on secondary markets, not new bonds to finance budget deficits. The goal of the OMT is not to reduce borrowing costs to an artificially low level, but to prohibit interest rate increases which are not justified by economic fundamentals.'

${ }^{134}$ ECB Press Release, 'Technical Features of Outright Monetary Transactions', Frankfurt, 6 Sept. 2012.

${ }^{135}$ Ibid. 
are allowed to be traded on a regulated market in compliance with Directive 2004/39/EC on markets in financial instruments. ${ }^{136}$

Although certainly unconventional in nature, the bond-buying activities of the ECB seem to stay within its monetary policy competences and not to violate the prohibition on monetary financing. ${ }^{137}$ That fact that they also have a positive impact on financial stability is in accordance with the financial stability mandate of the ECB in Article 127(5) TFEU. ${ }^{138}$ Most importantly, interventions under the OMT will only take place for as long as is warranted from a monetary policy perspective and they will be terminated once their objectives have been achieved. ${ }^{139}$

Therefore, contrary to the ESM, which is a permanent result of the transition from negative to positive solidarity, the OMT applies only temporarily. It facilitates the change in normative solidarity that is characterized by the increasing importance of financial stability. After all, several structural reforms are underway to break the vicious circle between sovereigns and banks in order to better safeguard financial stability in the future. Two deserve to be mentioned specifically. First, in the course of 2013 a single supervisory mechanism for banks should be established, ${ }^{140}$ to be followed by a single resolution mechanism as well. ${ }^{141}$ Second, after the establishment of this supervisory mechanism the ESM should be granted the power to recapitalize ailing banks directly. ${ }^{142}$ That is, without the assistance being granted via the recipient bank's member state, thereby further deteriorating its budgetary

${ }^{136}$ Directive 2004/39/EC of the European Parliament and of the Council of 21 April 2004 on markets in financial instruments amending council Directives 85/611/EEC and 93/6/EEC and Directive 2000/12/EC of the European Parliament and of the Council and repealing Council Directive 93/22/EEC, OJ [2004] L 145/1, last amended by Directive 2010/78/EU of 24 Nov. 2010, OJ [2010] L 331/120; C. Herrmann, 'EZB-Programm fur die Kapitalmarkte verstosst nicht gegen die Verträge - Erwiderung auf Marting Seidel, 21 EuZW (2010) p. 645 at. p. 646. In support of a broader reading of the term the latter also refers to Smits, supra n. 22, p. 264 (noting that 'the English term 'marketable instruments' is very wide in ambit and encompasses more than the German 'börsenängige Wertpapiere').

${ }^{137}$ See also R. Smits, 'Correspondence - The European Debt Crisis and European Union Law: Comments and a Call for Action', 49 CMLR (2012) p. 827 at p. 829.

${ }^{138}$ Herrmann, supra n. 132, p. 810-812. To the contrary see Seidel, supra n. 125, p. 521.

${ }^{139}$ European Central Bank, Monthly Bulletin October (ECB 2012), p. 8.

${ }^{140}$ See Proposal for a Council Regulation conferring specific tasks on the European Central Bank concerning policies relating to the prudential supervision of credit institutions, Brussels, 12 Sept. 2012, COM(2012)511 final; Proposal for a Council Regulation of the European Parliament and of the Council amending Regulation (EU) 1093/2010 establishing a European Supervisory Authority (European Banking Authority) as regards its interaction with the Council Regulation conferring specific tasks on the European Central Bank concerning policies relating to the prudential supervision of credit institutions, Brussels, 12 Sept. 2012, COM(2012)512 final.

${ }^{141}$ European Council, Conclusions, Brussels, 13-14 Dec. 2012, para. 11.

${ }^{142}$ Euro area summit statement, Brussels, 29 June 2012; European Council Conclusions on completing EMU, Brussels, 18-19 Oct. 2012, para. 10; European Council, Conclusions, Brussels, 13-14 Dec. 2012, para. 10. 
situation. It seems, therefore, that of the above 'impossible trinity' it is not the prohibition of monetary financing, but the interdependence between sovereigns and banks that will eventually have to give.

\section{THE FUTURE DEVELOPMENT OF SOLIDARITY IN THE CURRENCY UNION}

The above analysis shows how solidarity between member states in the currency union develops over time. It also proves that the current treaty framework of EMU can incorporate this shift. However, as with any legal rule, there are limits to the ability of the existing EU treaties to adjust to such changes in solidarity. One can already discern two developments which may reach beyond the limits of the current instruments.

The first concerns a change in normative solidarity, inherent in a shift in focus from financial stability to what may be called political stability. Two crucial declarations may serve to pinpoint this change in normative solidarity. The first was issued by the euro area Heads of State or Government shortly before they decided to establish the EFSF in May 2010: 'In the current crisis we reaffirm our commitment to ensure the stability, unity, and integrity of the euro area. ${ }^{143}$

The second statement was issued by German chancellor Angela Merkel on 15 December 2010 in the Bundestag: 'No one in Europe will be left alone. No one in Europe will be allowed to fall' [Niemand in Europa wird allein gelassen. Niemand in Europa wird fallengelassen]. ${ }^{144}$

Both statements are proof of a willingness to grant aid to a member state in order to secure the integrity of the currency union, even if the recipient member state does not pose a threat to financial stability. Legally speaking, the granting of aid in such situations cannot be realized via the ESM, as Article 3 of the ESM Treaty explicitly states that the granting of aid by the ESM must serve the objective to safeguard financial stability. More importantly, however, it is likely that the granting of such aid would also run counter to the no-bailout clause in Article 125 TFEU.

The Court has not gone so far in its Pringle judgment as to deny Article 125 TFEU the objective of securing the political stability of the currency union. ${ }^{145}$ When identifying the objectives of the no-bailout clause that can justify the grant-

\footnotetext{
${ }^{143}$ Statement of the Heads of State or Government of the euro area, Brussels, 7 May 2010.

${ }^{144}$ Regierungserklärung von Bundeskanzlerin Merkel zum Europäischen Rat am 16. und 17. Dezember in Brussel, Berlin, 15 Dec. 2010, <www.bundeskanzlerin.de/Content/DE/Regierungs erklaerung/2010/2010-12-15-merkel-regerklaerung-eu.html>.

${ }^{145}$ For a discussion to what extent it can be argued that Art. 125 TFEU indeed serves such an objective, see Borger, supra n. 74, p. 137-138.
} 
ing of assistance, it did limit its findings to financial stability. ${ }^{146}$ It cannot be ruled out, however, that the Court will be confronted with the issue of political stability in relation to Article 125 TFEU in the future. ${ }^{147}$

The second development relates to a further transition from negative to positive solidarity. The ESM is only a step (albeit a big one) in the on-going transformation process of economic governance of the Union. Both Commission president Barroso and European Council President Van Rompuy have presented plans to strengthen the EMU. ${ }^{148}$ The Commission, in particular, has set out in detail its vision on the future of economic governance in the Union. Over the medium term it proposes to establish a Redemption Fund as well as the introduction of Eurobills. ${ }^{149}$

The plan for a Redemption Fund was first proposed by the German Council of Economic Experts. ${ }^{150}$ On the basis of this plan euro area member states would establish a Redemption Fund that would benefit from their joint and several guarantees. The idea is essentially that these guarantees reduce the financing costs of the Fund which, in turn, makes it possible to pass on the advantage of these lower interest rates when buying debt of euro area member states on the primary market. ${ }^{151}$ Subject to strict conditions and in return for consolidation efforts, euro area member states would transfer their debt exceeding the SGP reference value

${ }^{146}$ Case C-370/12, Pringle, para. 135.

${ }^{147}$ This could happen in relation to Cyprus, which has lodged an official request for financial assistance on 25 June 2012. See Statement by the President of the Eurogroup, Brussels, 25 June 2012. See also Statement by the Eurogroup, Brussels, 27 June 2012. Certain members of the German parliament are questioning whether Cyprus qualifies for assistance of the ESM. They argue that its economy is too small to pose a threat to the financial stability of the currency union. See 'German Musings: Is Cyprus too Small for a Bail-Out'?, EUobserver.com, 30 Jan. 2013, <euob server.com/economic/118893>. Interestingly, in its opinion on the draft of Decision 2011/199 the European Parliament already stressed that all states should be able to call on the ESM, even those whose economies are too small to pose a threat to the financial stability of the euro area as a whole. See European Parliament Resolution on the draft European Council Decision amending Art. 136 TFEU, para. 6. See also Borger, supra n. 74, p. 137.

${ }^{148}$ H. Van Rompuy (in close collaboration with J. M. Barosso, J-C Junkcer and M. Draghi), Towards a Genuine Economic and Monetary Union, Brussels, 5 Dec. 2012; European Commission, 'A Blueprint for a Deep and Genuine Economic and Monetary Union - Launching a European Debate', Brussels, 30 Nov. 2012, COM(2012) 777 final/2 (henceforth: 'Commission blueprint for a deep and genuine EMU').

${ }^{149}$ Commission blueprint for a deep and genuine EMU, supra n. 148, p. 26, 28-30 and Annex 3.

${ }^{150}$ See Sachverständigenrat zur Begutachtung der gesamtwirtschaftlichen Entwicklung, Verantwortung für Europa nehmen (Jahresgutachten 2011/12). An English translation of the proposal is available at <www.sachverstaendigenrat-wirtschaft.de/fileadmin/dateiablage/Sonstiges/chapter_ three_2011.pdf>.

${ }^{151}$ See also P. Bofinger et al., 'A Redemption Pact for Europa: Time to Act Now', 25 July 2012, $<$ www.voxeu.org/article/redemption-pact-europe-time-act-now>. 
of $60 \%$ to GDP to the Fund during a 'roll-in phase' of five to six years. Member states would individually redeem their transferred debt over a period of 20 to 25 years. After this period, and because of the lower refinancing costs for the transferred debt, highly indebted countries should have brought down their debt to $60 \%$ of GDP.

Eurobills, as envisaged by the Commission, would involve a common issue, on the basis of joint and several guarantees, by euro area member states of short term debt with a maturity of 1 to 2 years. ${ }^{152}$ Such securities could stabilise government debt markets and lower interest rates, thereby bringing down financing costs for peripheral member states. In addition, they may facilitate financial stability as they counteract the interdependence between member states and the domestic banks that hold their government debt. ${ }^{153}$

However, and as admitted by the Commission itself, ${ }^{154}$ both initiatives would, most probably, require an amendment of the Union treaties in light of the nobailout clause in Article 125 TFEU. The problem is not so much that they run counter to the requirement, stipulated by the Court in Pringle, that assistance can only be granted when this is indispensable for the safeguarding of financial stability. It can be argued that from the reasoning of the Court it becomes apparent that this ultima ratio condition only applies to crisis resolution mechanisms such as the ESM and not necessarily to all financing instruments. ${ }^{155}$ Rather, given that both plans resort to the use of joint and several guarantees in some respect, they sit uncomfortably with the Court's finding that member states are not allowed to guarantee the debt of their partners and that each state must stay responsible for its financial commitments. ${ }^{156}$

However, what is more important than the legal hurdles that have to be taken to facilitate the ongoing development of solidarity in the currency union, is the legitimation of this process. Especially the increasing shift from negative to positive solidarity between euro area member states will only prove durable if it enjoys the support of their peoples. Without that support, in the end, the law will not suffice as an agent of change.

${ }^{152}$ On the issue of Eurobills, see also T. Philippon and C. Helwig, 'Eurobills, not Eurobonds', 2 Dec. 2011, <www.voxeu.org/article/eurobills-not-euro-bonds>.

${ }^{153}$ Commission blueprint for a deep and genuine EMU, supra n. 148, p. 29-30.

${ }^{154}$ Ibid., p. 26, 29-30.

${ }^{155}$ This becomes especially apparent from the Court's statement that 'the activation of financial assistance by means of a stability mechanism such as the ESM is not compatible with Art. 125 TFEU unless it is indispensable for the safeguarding of the financial stability of the euro area as a whole and subject to strict conditions.' See Case C-370/12, Pringle, para. 136.

${ }^{156}$ Case C-370/12, Pringle, para. 145 . On the issue of joint and several liability in relation to Art. 125 TFEU, see also De Gregorio Merino, supra n. 96, p. 1630-1632. 